\title{
Unseen Contributor to the Tensions in Georgia
}

\author{
Vladimir Liparteliani \\ Department of International Relations and Journalism, Adam Mickiewicz University, Poznan, Poland
}

\begin{abstract}
The purpose of the research is to examine importance of Georgia's current relations with its neighboring Russia and Azerbaijan and to estimate risks that deterioration of these relations can bring to Georgia's economy. Of particular interest is to understand who stands behind the tensions happened in Georgia in the run-up to the tourist season of 2019 or at least to figure out possible motives behind the events. Interdependence of the states is analyzed through historical review of their relations and estimation of their current mutual interests. Considering risks and aspirations of the sides in the tensions, the motives behind are suggested. The data received depicts that none of these tensions were initiated by Georgia following its interests, on the contrary, its ruling party's most visible achievement had been the ability to maintain positive and beneficial relations with both Russia and Azerbaijan. Thus, the Georgian government considered to be a victim in this case. The paper concludes that Georgian government is unable to react on provocations in a timely fashion due to absence of agreement in the ruling party and being quite fragile for outside forces that try to influence the country's political processes. Unless Georgia manages to build more interdependent or less dependent relations with superpowers, it will be unable to avoid repetition of such manipulations.
\end{abstract}

Keywords: Tensions in Georgia; Protests in the caucasus; Azerbaijan and georgia's relations; Russia's influence in the caucasus.

(4) (4) CC BY: Creative Commons Attribution License 4.0

\section{Introduction}

One of the main priority directions for Georgia's economy is development of tourism sector, which is closely linked to neighboring countries and based on improved relations with them. According to recent statistics some of the most important players in this field for Georgia are Russian and Azerbaijani tourists. Collectively they make up for more than one-third part of the total tourists who visited Georgia in 2018. However, as the 2019 summer season was approaching, the high season for tourism in Georgia, relations with both neighbors suddenly soured. The crisis created a real threat for the whole tourism industry, and when buttressed with an already difficult economic situation and currency crisis in Georgia, its impact was felt across many segments of the economy. According to National Bank, due to sanctions imposed by Russia, Georgia will suffer losses of approximately 300 million dollars in 2019 (Forbes, 2019). Furthermore, parallel deterioration of relations with Azerbaijan may only aggravate the situation.

This research will analyze importance and perspectives of relations with both neighbors Russia and Azerbaijan and evaluate risks associated with the current tensions and estimate what impact they can have on Georgia, and discuss the possible motives behind the events of 2019. The research will contribute to understanding of the role of economic and cultural ties between these three states for Georgia's stability. The results of this analyses play important role in determination of the right position for Georgia's external policy decision makers as it clearly depicts the weak points of the state's foreign agenda. The research will also be useful in attempt to clarify Russia's foreign policy's agenda towards Georgia and tools it uses to influence the South Caucasian state.

\section{Methodology}

In order to evaluate both risks and importance of the current tensions between Georgia with its neighboring Russia and Azerbaijan, it is necessary to determine roles of these states as they impact Georgia's much needed stability - both geopolitically and in terms of economics. Hence the sense of relations between neighbors should be understood through historical analyses and close ties, and what current factors are able to provide mutual benefits for these countries, and what synergies they provide for each other. On the basis of the risk's significance it appears to be able to further describe whose interests may stand behind the tensions.

\subsection{Tourism - Country's Priority}

The previous government, of the United National Movement, UNM, place a high priority on tourism a mechanism for economic growth. The same emphasis was continued successfully by the Georgian Dream party in the wake of the 2012 Georgian parliamentary elections.

Regardless of the strong criticism towards the current government in terms of a claimed increased level of corruption than compared with the period of the UNM (Saertashoriso gamchirvaleba - saqartvelo, 2019), recorded criminal violation total (32.263 in 2011 vs. 58.412 in 2018) (Geostat, 2019a), and accusations of informal ruling, the fact that tourism sector has done significant progress is undisputed with two fold increase after 2011 (Gnta, 2019). 
However it is worth mentioning that the commitment to work towards the creation of a "Touristic Paradise" and Georgia being a preferred destination was endorsed during the Saakashvili's period and the first massive wave of investments was made at that time. The influx of investment served as a first step in bringing Georgia to a new level.

The concept was most clear: Georgia needed money and investments in order to develop infrastructure whereas on the other hand, it would bring in tourists who were supposed to boost economy growth. The exact same program has been followed by the Georgian Dream but its efforts were even more successful than its predecessor.

Thanks to more or less normalized relations with Russian government than compared with the National Movement, the flow of Russian tourists has drastically increased. Not only in touristic sphere improvement can be positively mentioned, but Georgia's export indicators in terms of exports to the Russian Federation have also undergone enormous growth and now represent the lion's share of total export (Geostat, 2019b).

On the other hand, relations that the new Georgian government, represented by Georgian Dream, has managed to develop with the European Union should be mentioned as they have been raised economic indicators to a new level. Reforms and the proposed Association Agreement, as represented DCFTA, were supposed to, and finally have contributed to the economic development of the country (Modebadze, 2019).

The most visible achievement has been a free visa regime with the EU, which has become a symbol of country's European success. Collectively improved relations could be called exemplary, and this also includes relations with Azerbaijan and Turkey: no-visa regime and a constant touristic flow from other close countries, Iran and Armenia, and buttressed with closer cooperation on all levels with the EU.

However, steady improvement does not mean ideal relations with Russia. Georgia had been benefiting from all its neighbors, including Russia (I do not touch upon the issue of the breakaway regions of South Ossetia and Abkhazia, and this lack of detail is intentional as it is beyond the scope of this paper) - especially in terms of economic, political and cultural affairs. Thus, all these other considerations started appeared as something unrealistic, and very transitory for Georgia, which has always been in at least difficult or even in hostile relations, with at least one of its neighbors.

\subsection{Relations with partners: Azerbaijan and Russia}

In this section Georgia's relations with Azerbaijan and Russia and shared points for mutually beneficial cooperation will be discussed on the basis of economic, cultural and political relations. The aim is to demonstrate how closely tied these three countries are. Thus, to estimate and reduce potential risks that add to tensions between Georgia and its neighbors.

\subsubsection{Azerbaijan}

Georgia and Azerbaijan though being of different cultural heritage, predominately Christianity on one side and Turkic-Muslim identity on the other, has influenced one another in many ways. At times it has even created common cultural crossovers. To list all cultural links between these two nations would be impossible within the scope of this article but the most prominent will be further discussed.

A substantial number of Azerbaijani intellectuals, poets and writers who lived at the end of the $19^{\text {th }}$ century were working in Tbilisi. They were active in circulating many progressive ideas and thus facilitating cultural cooperation between two countries. Publishing newspapers and magazines in the mother tongue in the second half of the $19^{\text {th }}$ century had a positive impact on the Azerbaijani’s cultural development (Kakachia and Shiriyev, 2019).

For instance, in 1878 in Gori, at the Transcaucasia Teacher Seminary an Azerbaijani (Tatar) Department was established, known for its prominent graduate, playwright and contributor to purity of Azeri language Mirza Fatali Akhundov (2000), reveals much. It represented a brilliant example of a common cultural past and such work served as a masterpiece of an author with a disputable identity. Kurban Said published his novel in more than 30 languages «Ali and Nino: a love story» (Azer, 2019). «The novel is frequently cited in the news when ethnic conflicts break out in the Caucasus and Foreign Policy magazine listed it as one of "The foreign-policy books you should be reading to get ready for election season" (Eurasia, 2019).

The novel serves as a symbol of good neighborly relations between two countries and a statute of Ali and Nino in Batumi is considered to be one of modern landmarks of the city being very popular among tourists particularly from Azerbaijan.

Not only cultural ties, dating back, are strengthening these countries relations, but some very important recent regional projects, such as the Baku-Tbilisi-Ceyhan (BTC) and Baku-Supsa oil pipelines. The Baku-Tbilisi-Erzurum (BTE) gas line can also be included on this list, creating strong and deep economic and political ties between Azerbaijan, Georgia and Turkey. This also supports interests of the West as a corridor East-West serves as an alternative route for bringing Caspian oil and gas to Europe. Notably that Azerbaijan supplied 90 percent of Georgia's gas demand at the lowest rates among SOCAR's clients prices (Mendyk, 2019).

Development and upgrading of Georgia's transport infrastructure to bring it compliance with European standards is a priority direction for Georgia's Foreign Policy Strategy, thus the Baku-Tbilisi-Kars railway project is of highest importance. It is going to link two countries with centralized European railway network and that is a high priority for the Black and Caspian Sea regions (Web, 2019).

Additionally, Azerbaijanis living in Georgia represent the biggest ethnic minority in the country and account for $7 \%$ of the population (Nplg, 2019). Majority inhabits the Kvemo Kartli region, known also as Borchali among Azerbaijanis, where they make up roughly half of the citizenry with 45,1\% (Mikadze, 2019). 
This fact should be very carefully evaluated, as without closer understanding, local demands could work against Georgia's territorial integrity interests and vice versa. If potential issues could be addressed property, it could be beneficial to the state, provided that it follows the path of a consistent and level policy.

Moreover, concurrently, there are about 10,000 ethnic Georgians called Ingiloys living in north-western Azerbaijan. The main difference between them and Georgians in Georgia is religious affiliation, while some of them are still Christians, many follow Islam.

In spite of potential conflicts and differences, Georgia remains a popular destination. It is becoming more and more attractive for Azerbaijanis. Firstly, they visit the Black Sea region and health resorts during summer holidays. They also come to Georgia during other times to access medical treatments, mainly based on better service and value for the money. Just over one in five tourists to Georgia comes from Azerbaijan (20, $4 \%$ ) from the total amount of visitors who came to Georgia during the first quarter of 2019 (Geostat, 2019c), which is the second highest numbers.

Stated above is a prime example of interdependence between Azerbaijan and Georgia culturally, economically and politically, which must be used by both states for mutual benefit and they must be aware of how third parties may at times try intervene in such mutually win-win situations.

\subsubsection{Russia}

Discussions of relations of these two countries bring forth more questions than they can provide us with answers and this topic is highly debatable. What these countries have common is greater than their differences. From the very beginning of the relations, in end of the $18^{\text {th }}$ century, the uniting force proved to be Orthodox Christianity and the belief that Russia would assume the role of protector. Generally, the way Russia is presenting to Georgia itself today has not been dramatically changed since earlier periods of history.

Georgian policy towards Russian bears ambivalent character due to Georgia's attempts to recover control over the defector breakaway regions Abkhazia and South Ossetia after mass expulsions of ethnic Georgians from these region, and on the other hand, the importance of cooperation in economic and socio-cultural issues.

The current ruling party of the Georgian Dream has drastically improved relations with Russia (in comparison with Saakashvili's period) and it has managed to gain benefits, including being able to sell greater quantities of wine and mineral water to the Russian market. A positive attitude by most Russians makes Georgia one of top most popular tourist destinations for its citizens (Russiatourism, 2019).

The factor is very important as the popularity of the destination had only been growing until the June 2019. It is worth mentioning that Georgia has been able to become one of the leading destinations for Russian tourism in spite of political crises between the states and absence of official diplomatic relations. The important step towards that helped in the tendency was the implementation of visa-free regime for Russian citizens. This policy was introduced by President Saakashvili in 2012 (Regnum, 2019).

Nonetheless, all such measures were implemented under the shadow of demands by many Georgians to address the problem of the "occupied territories" and to address the need to bring about an urgent resolution to the issue.

The government has also been absolutely clear in its position with regard to the country's territory integrity, however, in spite of lack of progress, has somehow managed to balance it with closer collaboration. Although, modern Russia today still has an image of an empire and is often associated by many Georgians as a country wishing to seize their lands, the government has used a rational approach to balance its position. It has been successful, at least until recently, to accomplish both goals at once: oppose occupation and gain benefits from trade and tourism.

However, some consider this as one of the few advantages that has been achieved since the Georgian Dream party has been in control. There are still many question marks in terms of potential closer cooperation, for example Giga Otkhozoria and Archil Tatunashvili’s issues (Agenda, 2019a).

\subsection{Tensions and their Meaning}

\subsubsection{Georgia-Azerbaijan}

In spite of the fact that just over a third, (35\%) of the 480 kilometer border between Georgia and Azerbaijan has remained un-delineated for decades, a significant diplomatic dispute has resulted and has led to negative political statements by various purported stakeholder and public protests on both sides. The difficultness of the issue is that border is dividing historic complex called David Gareji in Georgia or Keshishdag in Azerbaijan.

This debatable border delimitation happened in 28 January 1922 and remains bone of contention until today for these two countries. The Soviet Government made decisions according to their politically expedient interests at that moment, thus trying to 1) make it extremely difficult to undone that decision of border delimitation 2) make the republics' future as much as possible dependent on Moscow in many cases. Today the issue is also complicated by the fact that each of these two possesses and recognizes different facts and sources with regard to history of the complex. Georgian side considers it as a part of its culture, while Azerbaijan's side counts it is a monument of Albanian culture.

Although many attempts were used to finally find solution, for example Georgian side suggested to swap the complex in exchange for some other territories, no agreement has been made yet unfortunately (Sainformacio analitikuri portali, 2019). The reasons for impossibility for this exchange to become true is that it could give precedent for the Karabakh issue. If Azerbaijan gives the territory to Georgia on the basis of the last's claims to control the complex as it is a part of Georgian culture and religion, then it would mean that Armenian's claims on Karabakh do have a legal and justified reasons. 
It would also jeopardize the concept of Azerbaijan state as the multicultural one that incorporates peoples and lands of different ethnicities and unite them under one common governmental idea. The brilliant example for it is Turkey, closest ally of Azerbaijan. Thus this exchange would serve as a time-bomb as there are enough premises in Azerbaijan for possible separatism by other ethnic groups living within the country today.

Normally peaceful situation on the Georgian-Azerbaijan border abruptly flared up when Georgian President Salome Zurabishvili was visiting complex in April 2019. She had called for an effort to finalize the delimitation talks. Later, on the eve of Orthodox Easter, Azerbaijani border guards restricted access to part of the complex, hence causing resentment from Georgian worshippers, especially monks and tour guides.

Additionally, the entry to the medieval monastery of Udabno was blocked, where amazing Georgian frescos of utmost importance for Georgians are maintained. These events caused serious concerns from Georgian Church Officials. Heated by the events, both Georgians and Azerbaijanis started to debate and argue in online message boards, thus causing even greater dissonance.

Relatively peaceful rallies were held by Georgian side both along the border near David Gareji and in from of the Azerbaijani Embassy in Tbilisi (Civil, 2019). Several days after the two countries foreign ministers agreed to reopen access but the tension had still been existing and in several weeks finally converted in harassing Azerbaijani boarder guard by Georgian activists and grabbling a pistol from him (YouTube, 2019a). Although both governments reacted on these particular episodes similarly with condemnation, they hold completely different positions over the border demarcation issue (Eurasia, 2019).

Due to the above discussed importance of the border issue for both sides, it now appears that is premature to predict any significant changes and final resolutions at the moment. The repercussions, if one of sides attempts to solve the problem unilaterally, will be too grave and not worthy for any of the stakeholder.

All this should be discussed in light to the above discussed economic, cultural and social interdependence, and most importantly, perspectives for future cooperation, however, if emotions are allowed to prevail, irrational behavior and decisions may prevail. Hence, we can clearly observe that neither Georgia nor Azerbaijan can benefit from escalation of this border issue, rather than possible third parties.

\subsubsection{Georgia-Russia}

Understanding the problems faced by these countries relations is essential in looking at larger geopolitical issues. Few expected the issues that resulted over the unresolved border delineation, and this brought about tense relations over David Gareji and its ownership. However, in light of what has been mentioned and gradually improving relations within the last seven years, pundits and laypersons can at least can easily observe the consequences, particularly on the Georgian economy.

The main sticking point for deterioration in relations was, as Russian side is treating it, the breakout of antiRussian protests in Tbilisi, however from the very beginning protest were first described as anti-governmental with the aim of overthrowing the legally elected Georgian government.

Only later did the protests start to contain anti-occupational direction, albeit rather symbolic. Protesters accused the government in allowing Russian MP Sergey Gavrilov to chair the general assembly of the Interparliamentary Assembly on Orthodoxy (IAO) (RadioFreeEurope/RadioLiberty, 2019). The position of protesters was based on the fact that Mr. Gavrilov was officially representing the country which, many in Georgia, describes as an occupier.

Consequently he had to leave Georgia urgently and proceedings were disrupted. The second event what happened was an ill-timed and insulting speech of TV host Giorgi Gabunia, who personally addressed Vladimir Putting with highly offensive language; it is worth mentioning that this all happened within the background of two weeks of going protests (YouTube, 2019b).

As the result, Russia considered Georgia to be dangerous for its citizens and banned all direct flights to the country. It also prohibited Russian tour agencies from booking travels to the country (Agenda, 2019b), thus seriously harming the Georgian tourism sector.

Tbilisi is now on the list of European cities with hardly any Russian tourists (CNN Travel, 2019). There were also attempts by Duma to impose tough economic sanctions on Georgia after the insulting speech, however Russia's President did not support the parliamentary call.

It does not appear as if all what has transpired was happenstance, not by chance but rather a series of events that were planned.

In retrospect it is difficult to imagine that members of the ruling party did not know that Russian MP was going to visit Georgia and chair the assembly. It appears they could not or did not want stop Mr. Gavrilov from coming to the country. But rather used this as something of a false flag for political gain.

Nonetheless, such efforts backfired in the final analysis, having a negative impact, not only for Georgia but the United National Movement. It is the Georgian economy that has been weakened and society further divided, and many are more confused as to the political orientation of the country and who actually stands behind such events.

As for the Russian Federation, it becomes a story of "I hate to tell you so but I told you so, as Georgia is unpredictable and not a reliable or trusted party, too emotional.

Russian has been able to prove its cool political standing in face of provocations, not pushing all Georgians for the actions of a provocation. Many Georgians now see Russia as a more reliable partner and having greater patience. Russia now has more levers to wake up pro-Russian supporters in Georgia, and it has still not used its main trump ban for all Georgian import as it would have more economic consequences.

It is worth mentioning that Vladimir Putin's "gesture of goodwill" in not imposing economic sanction after the insulting speech by G. Gabunia will bring Russia a huge geopolitical advantage. Moreover, the possible cancelation 
of visa regime for Georgians, currently being actively discussed in media (Новости and Новости, 2019), is now being used by Russians as a "carrot," and such proactive actions only activates pro-Russian sentiments among Georgians - thus setting the stage for the greater support by the population for what they perceived as practical Russian policy.

On the other hand, the actions of Georgian opposition in this case can be estimated as a serious miscalculation and almost a complete failure. We can assert with certainty that the Gabunia's speech was not spontaneous and based on heated emotion, it was delivered with the clear intention of worsening relations between countries, hence Georgian Dream, pro-Russians and Russia's government and destabilise an already difficult situation. If Putin would had taken stricter measures and economic sanctions it would play into the hands of opposition. However Russia did not do it — and this event was used as a way of actually improving Georgian-Russian relations.

\section{Results}

We can clearly see how important for Georgia having positive peaceful relations with Russia and Azerbaijan, and not only in terms of maintaining the priority role of tourism in the country's economic development strategy. It is particularly crucial, as the states maintain good perspectives and opportunities for improving relations in the future. Taken together, due to good economic, cultural and political basis, many barriers can be overcome. However we should not ignore that problems still exists on both sides. It is clear that under the circumstances that Georgia currently does not possess any leverage needed to bring about a quick resolution of these issues. However, it is definitely not in its interests to exacerbate situations, either with Russia or Azerbaijan. Hence, it is becoming clear that third parties, with others in the shadows, have an agenda in intervening into Georgia's relations with its neighbors, or that some force, domestic or international, desires for one of these neighbors to position itself to dictate the terms and conditions to impact Georgia's policy direction.

\section{Conclusion}

Analyzing the given information, and in light of how events moved so quickly, it is clear that Georgia did not initiated any actions in the neighborhood itself, but rather it found itself as being hold hostage. This was because of government inability to sufficiently react in time to provocations in a timely fashion. It is clear that outside forces, regardless of the true motivations, want to influence Georgia from near and far.

The ruling Georgian Dream party has not demonstrated any certain leverage in building its foreign policy basing on National interests. But rather it maintains a defensive position and only reacts. It is clear that based on the country's economic dependence on its neighbors that Georgia may at times be doomed to be manipulated, at least until it will be able manage to build less dependent relations or more interdependent with its neighbors (as for example with Azerbaijan).

The most important task at hand is to achieve such a status and without damage being inflicted to the national economic as well as its cultural and political interests. This will be a challenge for the country for now and into the foreseeable future.

\section{References}

Agenda, g. (2019a). Gov’t puts 33 people on Otkhozoria-Tatunashvili list. Available: http://agenda.ge/en/news/2018/1360

Agenda, g. (2019b). Putin bans flights to Georgia, orders return of Russian citizens to homeland. Available: http://agenda.ge/en/news/2019/1659

Azer, c. (2019). 12.3 ali and nino covers - 37 languages. Available: http://azer.com/aiweb/an_covers/123_ali_nino_cover.html

Civil, g. (2019). New rally at david gareji monastery | civil.Ge. Available: https://civil.ge/archives/306959

CNN Travel (2019). 20 beautiful European cities with hardly any tourists. Available: https://edition.cnn.com/travel/article/beautiful-european-cities-few-tourists/index.html

Eurasia, R. (2019). Ali and nino's enduring mystique - analysis. Available: https://www.eurasiareview.com/24032012-ali-and-nino\%E2\%80\%99s-enduring-mystique-analysis/

Forbes, G. (2019). Rusuli agrzalvis gavlena - negatiuri da pozitiuri prognozebi. Available: https://forbes.ge/news/6695/rusuli-akrZalvis-gavlena

Geostat, g. (2019a). Siskhlis samartlis statistika - saqartvelos statistikis erovnuli samsakhuri. Available: https://www.geostat.ge/ka/modules/categories/132/siskhlis-samartlis-statistika

Geostat, g. (2019b). Sagareo vacroba - saqartvelos statistikis erovnuli samsakhuri. Available: https://www.geostat.ge/ka/modules/categories/35/sagareo-vachroba

Geostat, g. (2019c). Utskho vizitorebis statistika - sakartvelos statistikis erovnuli samsakhuri. Available: https://www.geostat.ge/ka/modules/categories/102/utskhoel-vizitorta-statistika

Gnta, g. (2019). kvlevebi | saqartvelos turizmis erovnuli administratsia. Available: https://gnta.ge/ge/\%E1\%83\%A1\%E1\%83\%A2\%E1\%83\%90\%E1\%83\%A2\%E1\%83\%98\%E1\%83\%A1\%E $1 \% 83 \% \mathrm{~A} 2 \% \mathrm{E} 1 \% 83 \% 98 \% \mathrm{E} 1 \% 83 \% 99 \% \mathrm{E} 1 \% 83 \% 90 /$

Kakachia, K. and Shiriyev, Z. (2019). The foundations and challenges of the strategic alliance. Available: www.researchgate.net

Mendyk, B. (2019). Bringing russian and iranian gas to the georgian market: Technically challenging, economically unfeasible and politically costly? Available: 
https://www.academia.edu/35919412/Bartosz_Mendyk_Bringing_Russian_and_Iranian_Gas to the_Georg ian_Market Technically_Challenging_economically_Unfeasible and_Politically_Costly

Mikadze, Z. (2019). Kvemo kartli | sakhelmtsifo rtsmunebulis administratsia, kvemo kartli. Available: http://kvemokartli.gov.ge/region

Mirza Fatali Akhundov (2000). Alphabet reformer before his time. Azerbaijan International, 8(1): Available: http://azeri.org/Azeri/az_latin/latin_articles/latin_text/latin_81/eng_81/81_akhundov.html

Modebadze, Z. (2019). DCFTA- $b \quad 1$ tseli shedegebis mimokhilva.| EUGeorgia. Available: http://eugeorgia.info/ka/article/343/dcfta-s-1-weli-shedegebis-mimoxilva/

Nplg, g. g. (2019). Ethnosebi saqartveloshi: azerbaijanelebi. Available: http://www.nplg.gov.ge/gsdl/cgibin/library.exe?e=d-00000-00---off-0civil2--00-1----0-10-0---0---0prompt-10---4-------0-11--10-ka-50---20about---00-3-1-00-0-0-01-1-0utfZz-8-00\&a=d\&cl=CL1.32\&d=HASH01539272c0a61b8f8dfb8ff9.8

RadioFreeEurope/RadioLiberty (2019). Furious anti-russia protesters in tbilisi demand speaker's resignation, clash with police. Available: https://www.rferl.org/a/anti-russia-protesters-in-tbilisi-demand-speaker-sresignation/30011083.html

Regnum, r. (2019). Available: https://regnum.ru/news/polit/1504531.html

Russiatourism, r. (2019). Viborochnaya statisticheskaya informacia, raschitanaya v sootvetstvii s Oficialnoi statisticheskoi metodologiei ocenki chisla v'ezdnix I viezdnix turisticheskikh poezdok - Rosturizm. Available: https://www.russiatourism.ru/contents/statistika/statisticheskie-pokazateli-vzaimnykh-poezdokgrazhdan-rossiyskoy-federatsii-i-grazhdan-inostrannykh-gosudarstv/vyborochnaya-statisticheskayainformatsiya-rasschitannaya-v-sootvetstvii-s-ofitsialnoy-statisticheskoy-metodologiey-otsenki-chislavezdnykh-i-vyezdnykh-turistskikh-poezdok/

Saertashoriso gamchirvaleba - saqartvelo (2019). Erovnuli aghkmis indeksi. Available: https://www.transparency.ge/ge/corruption/cpi

Sainformacio analitikuri portali (2019). Azerbaijanma davit garejis sadavo teritoris gacvlaze uari tqva. Available: https://for.ge/view/36121/azerbaijanma-daviT-garejis-sadavo-teritoris-gacvlaze-uari-Tqva.html

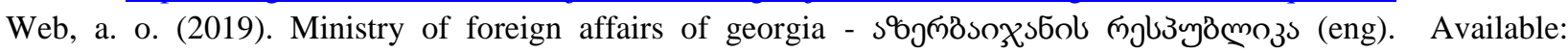
https://web.archive.org/web/20070927063947/http://www.mfa.gov.ge/index.php?sec id=334\&lang id=EN $\underline{\mathrm{G}}$

YouTube (2019a). Georgian nationalists stormed david gareja (keşikçidağ) monastry in Azerbaijan's territory. Available: https://www.youtube.com/watch?v=mYp5RV1iypg

YouTube (2019b). Expletive-laden putin rant on georgian tv leads to channel going off air - BBC News. Available: https://www.youtube.com/watch?v=re4dkJ3Iaks

Новости, Р. and Новости, Р. (2019). V MID ne iskluchili otmeni viz dlia grazhdan Gruzi'i. Available: https://ria.ru/20190718/1556631952.html 